\title{
Purification and Characterization of a Cysteine Protease Produced by Pathogenic Luminous Vibrio harveyi
}

\author{
Ping-Chung Liu, ${ }^{1}$ Kuo-Kau Lee, ${ }^{1}$ Chi-Ching Tu, ${ }^{1}$ Shiu-Nan Chen ${ }^{2}$ \\ ${ }^{1}$ Department of Aquaculture, National Taiwan Ocean University, 2, Pei-Ning Road, Keelung, Taiwan 202, ROC \\ ${ }^{2}$ Department of Zoology, National Taiwan University, Taipei, Taiwan 106, ROC
}

Received: 20 November 1996 / Accepted: 7 January 1997

\begin{abstract}
The purification and characterization of an extracellular protease produced by pathogenic luminous Vibrio harveyi strain 820514, originally isolated from diseased tiger prawn (Penaeus monodon), was presented in this paper. The purification steps included ammonium sulfate precipitation, with columns of hydrophobic interaction chromatography and anion exchange on fast protein liquid chromatography. The protease is an alkaline cysteine protease, heat labile, inhibited by iodoacetamide, iodoacetic acid, N-ethylmaleimide, $p$-chloromercuribenzoate, and $p$-chloromercuribenzene-sulfonic acid, and showed maximal activities at $\mathrm{pH} 8$ and $50^{\circ} \mathrm{C}$, having a molecular mass of $38 \mathrm{kDa}$ as estimated by SDS-PAGE and gel filtration column. In addition, the protease was also completely inhibited by $\mathrm{CuCl}_{2}$ and $\mathrm{HgCl}_{2}$, but not or only partially inhibited by other inhibitors tested. Furthermore, 2-mercaptoethanol was the most effective reducing agent in the activation of the enzyme. The present protease is the first cysteine protease found in Vibrio species.
\end{abstract}

Vibrio harveyi is commonly isolated from various habitats, i.e., warm marine waters, surfaces of marine animals, light organs of certain marine fish and cephalopods, and intestine of aquatic animals [3, 36, 42-44, 48]. Recently, the virulence of this species has been recognized in a small but growing list of marine animals especially in cultured penaeids in Asia and Australia [2, 6, $15,17,22,25,29,30,38,40,51,54]$. Mass mortalities of Penaeus monodon and larvae or juveniles associated with luminous vibrios have been observed in hatcheries or farms in Australia [40], India [17], Indonesia [54], Thailand [15], the Philippines [2, 25], and Taiwan [6, 29, 51].

Various extracellular proteases produced by a number of Vibrio species isolated from sea water, fish, and shellfish have been isolated and examined with regard to their enzymatic properties and/or virulence. Most of these studies are on the enzymes (mainly proteases) from Vibrio anguillarum, since its foremost importance is as a pathogen in fish $[8,9,14,31,33,53]$. Two extracellular proteases produced by $V$. alginolyticus NCMB 1339 and

Correspondence to: K.-K. Lee one metalloprotease produced by $V$. alginolyticus S3y have also been described to be toxic to larval Ostrea edulis [34, 35] and juvenile Epinephelus malabaricus [26], respectively. Three extracellular alkaline metalchelater-sensitive proteases produced by $V$. harveyi isolated from sea water have also been reported [10, 11]. However, no information is available concerning the extracellular protease(s) produced by pathogenic $V$. har$v e y i$ isolated from diseased penaeids.

In the present paper, an exoprotease has been purified from the extracellular products of Vibrio harveyi strain 820514 to apparent homogeneity by a combination of ammonium sulfate precipitation, hydrophobic interaction chromatography, and anion-exchange chromatography on fast protein liquid chromatography. The purified protease appears to be a cysteine protease by virtue of the inhibition of enzyme activity by iodoacetamide, iodoacetic acid, N-ethylmaleimide, $p$-chloromercuribenzoate, and $p$-chloromercuribenzene-sulfonic acid, and the partial or complete resistance to several inhibitors of serine protease, acid protease, and metalloprotease. The relationship of this protease to previously identified Vibrio proteases and cysteine proteases from other organisms is discussed. 


\section{Materials and Methods}

Bacteria and extracellular products (ECP). Luminous $V$. harveyi 820514 , originally isolated from diseased tiger prawn (Penaeus monodon) in Taiwan in 1993, was used in this study [29]. Stock cultures of strain 820514 were grown on tryptic soy agar (TSA; Oxoid, Basingstoke, supplemented with $1.5 \% \mathrm{NaCl}$ ) for $24 \mathrm{~h}$ at $27^{\circ} \mathrm{C}$. Two swabs of these bacteria suspended in $5 \mathrm{ml}$ phosphate-buffered saline (PBS) pH 7.2 were spread onto TSA $(+1.5 \% \mathrm{NaCl})$ overlaid with sterile cellophane and grown for $24 \mathrm{~h}$ at $27^{\circ} \mathrm{C}$. The ECP was harvested as previously described [27]. Briefly, $15 \mathrm{ml}$ of PBS was added to the surface of the cellophane overlaying TSA $(+1.5 \% \mathrm{NaCl})$ and spread completely. The harvested bacterial suspension was then centrifuged at $25,000 \mathrm{~g}$ for $60 \mathrm{~min}$ at $4^{\circ} \mathrm{C}$; the pellet was discarded. The supernatant fluids were passed through a $0.22-\mu \mathrm{m}$ filter (Millipore, Bedford), and the ECP was stored in $1-\mathrm{ml}$ aliquots at $-70^{\circ} \mathrm{C}$. Total protein was measured by the method of Bradford [5] with bovine serum albumin as standard. Protease activity was measured by hide powder azure (HPA) digestion as previously described [27]. Briefly, the enzyme solution (0.1 $\mathrm{ml}$ ) was incubated and shaken with $25 \mathrm{mg}$ HPA in $2.4-\mathrm{ml} \mathrm{PBS}$ at $37^{\circ} \mathrm{C}$ for $15 \mathrm{~min}$. On addition of $2.5 \mathrm{ml} 10 \%$ trichloroacetic acid (TCA) and after centrifugation, the absorbance of the supernatant was measured at $600 \mathrm{~nm}$. Blanks were prepared by addition of $10 \%$ TCA to substrate prior to the proteolytic assay. One unit of protease activity is an increase in absorbance of 0.01 unit. Caseinase, gelatinase, and phospholipase activities were detected by placing samples in wells cut in agarose (1\% in PBS, $\mathrm{pH} 7.2$ ) containing $0.2 \%$ (wt/vol) sodium caseinate, gelatin, and lecithin, respectively, and incubating in humidified chamber for $24 \mathrm{~h}$ at $25^{\circ} \mathrm{C}$. Hemolytic activity was measured by a standard microtitration method with sheep erythrocytes as described previously [27].

Purification of extracellular protease. To purify the extracellular protease, proteins in the ECP of $V$. harveyi 820514 were precipitated with $90 \%$ saturated ammonium sulfate (Serva, Heidelberg) for $60 \mathrm{~min}$ at $4^{\circ} \mathrm{C}$, collected by centrifugation at $25,000 \mathrm{~g}$ for $60 \mathrm{~min}$ at $4^{\circ} \mathrm{C}$, suspended in $50 \mathrm{ml}$ deionized distilled water, and dialyzed against 5 liters of deionized distilled water overnight at $4^{\circ} \mathrm{C}$. This dialyzed sample was then mixed with an equal volume of $2 \mathrm{M}$ ammonium sulfate in $100 \mathrm{~mm}$ phosphate buffer, $\mathrm{pH} 7.0$, then fractionated by fast protein liquid chromatography (Pharmacia, Uppsala) with a hydrophobic interaction chromatography (HIC, Phenyl Sepharose High Performance, Pharmacia) column equilibrated with $1 \mathrm{~m}$ ammonium sulfate in $50 \mathrm{~mm}$ phosphate buffer $\mathrm{pH}$ 7.0. Fractions $(4 \mathrm{ml})$ were eluted with 50 $\mathrm{mm}$ phosphate buffer, $\mathrm{pH} 7.0$, at a rate of $1 \mathrm{ml} / \mathrm{min}$. The fractions possessing protease activity were pooled, dialyzed against deionized distilled water overnight at $4{ }^{\circ} \mathrm{C}$, lyophilized, and then resuspended in 2 $\mathrm{M}$ ammonium sulfate in $100 \mathrm{~mm}$ phosphate buffer ( $\mathrm{pH}$ 7.0) prior to a further application to the same HIC-FPLC column with the same protocol. The fractions possessing protease activity were again pooled, dialyzed, and lyophilized as described above, and resuspended in $20 \mathrm{~mm}$ Tris (hydroxmethyl) methylamine (Tris buffer, $\mathrm{pH}$ 8.0) prior to fractionation by FPLC-anion exchange column (Q Sepharose High Performance, Pharmacia) equilibrated with $20 \mathrm{~mm}$ Tris buffer $(\mathrm{pH} \mathrm{8.0)}$. Fractions $(3 \mathrm{ml})$ were eluted with a sodium chloride gradient at a rate of $1 \mathrm{ml} / \mathrm{min}$. The fractions possessing protease activity were again pooled, dialyzed, and lyophilized as described above, and resuspended in $20 \mathrm{~mm}$ Tris buffer ( $\mathrm{pH}$ 8.0) and fractionated by FPLC-anion exchange column (RESOURCE Q, Pharmacia) equilibrated with $20 \mathrm{~mm}$ Tris buffer ( $\mathrm{pH}$ $8.0)$. Fractions $(2 \mathrm{ml})$ were eluted with a sodium chloride gradient at a rate of $1 \mathrm{ml} / \mathrm{min}$. The fractions possessing protease activity were again pooled, dialyzed, and lyophilized as described above, resuspended in 20 $\mathrm{mm}$ Tris buffer $(\mathrm{pH} 8.0)$, and fractionated by FPLC-anion exchange column (Mono Q, Pharmacia). Fractions $(1 \mathrm{ml})$ were again eluted with a sodium chloride gradient at a rate of $1 \mathrm{ml} / \mathrm{min}$. Aliquots of $1 \mathrm{ml}$ in Eppendorf were stored at $-70^{\circ} \mathrm{C}$.

Molecular mass determination. Phastgel gradient (8-25\%) polyacrylamide (Pharmacia) was employed in sodium dodecyl sulfatepolyacrylamide gel electrophoresis (SDS-PAGE) and used to check the purity of fractions and determine the molecular mass of protease. Pharmacia low-molecular-mass calibration kits were used as marker proteins. Electrophoresis was conducted on the PhastSystem (Pharmacia) according to the recommendations of the manufacturer. After electrophoresis, the gels were stained with Coomassie brilliant blue $\mathrm{R}$ 250 (Pharmacia). For molecular mass determination by gel filtration chromatography, the purified protease from the FPLC-anion exchange column was lyophilized, resuspended in PBS (pH 7.2), and $200 \mu \mathrm{l}$ applied to an FPLC Superose 12 gel filtration column (Pharmacia) that had been calibrated with standard marker (blue dextran, $2000 \mathrm{kDa}$; bovine serum albumin, $67 \mathrm{kDa}$; ovalbumin, $43 \mathrm{kDa}$; ribonuclease, 13.7 $\mathrm{kDa}$; Pharmacia). The sample was eluted with PBS at a rate of $1 \mathrm{ml} / \mathrm{min}$.

Protease zymogram. Purified protease was electrophoresed as the protocol described above for SDS-PAGE except that 2-mercaptoethanol was absent in the sample buffer (non-reduced) and the sample was not heated. After electrophoresis, the gels were stained with silver stain reagent (Pharmacia) for protein staining or overlaid with gels containing $1 \%$ agarose and $0.3 \%$ sodium caseinate in PBS for $2 \mathrm{~h}$ at $25^{\circ} \mathrm{C}$ for protease zymogram. Following removal of the overlay, the zymogram gels were stained with Coomassie brilliant blue R 250 .

Optimum pH, optimum temperature, and thermostability. For determination of optimum $\mathrm{pH}$, the purified protease preparation was added to various PBS buffer (vol/vol, 1:9) with $\mathrm{pH}$ adjusted from 3 to 10 with $1 \mathrm{~N} \mathrm{HCl}$ and/or $1 \mathrm{~N} \mathrm{NaOH}$, and then incubated for $2 \mathrm{~h}$ at $4^{\circ} \mathrm{C}$ prior to the protease activity assay (in duplicate) as described above. The highest protease activity was used as control (100\% of relative activity). For determination of optimum temperature, aliquots of the purified protease were incubated with HPA and assayed (in duplicate) as described above except that the enzymatic activities were determined at $5,20,25,30,35,40,45,50,55,60,70$, and $80^{\circ} \mathrm{C}$, separately. The highest protease activity was used as control ( $100 \%$ of relative activity). For determination of thermostability, aliquots of the purified protease were incubated for $30 \mathrm{~min}$ at $4,10,20,30,40,50,60,70$, and $80^{\circ} \mathrm{C}$, separately, and then directly put into an ice water bath prior to the protease activity assay (in duplicate) as described above. The protease activity of the sample incubated at $4^{\circ} \mathrm{C}$ was used as control $(100 \%$ of relative activity). Aliquots of the purified protease were further lyophilized, and the autodigestion of the enzyme was checked in SDS-PAGE as described above.

Enzyme inhibition. The effects of antipain (Sigma, St. Louis), Lcysteine (Sigma), dithiothreitol (Merck, Frankfurt), ethylenediamine tetraacetic acid (EDTA; Sigma), ethylene glycol-bis( $\beta$-amino-ethyl ether) $\mathrm{N}, \mathrm{N}, \mathrm{N}^{\prime}, \mathrm{N}^{\prime}$-tetraacetic acid (EGTA; Sigma), trans-epoxysuccinylL-leucylamido-(4-guanidino) butane(E-64; Boehringer Mannheim $\mathrm{GmbH}$, Mannheim), iodoacetamide (Serva, Heidelberg), iodoacetic acid (Sigma), leupeptin (Boehringer Mannheim GmbH), 2-mercaptoethanol (Serva), N-ethylmaleimide (Serva), $p$-chloromercuribenzoate (PCMB; Sigma), $p$-chloromercuribenzene-sulfonic acid (PCMBs; Sigma), pepstatin A (Serva), phenyl-methanesulfonyl fluoride (PMSF; Sigma), $N \alpha$-p-tosyl-1-lysine-chloromethyl ketone (TLCK; Sigma), $N$ tosyl-1-phenyl-alanine chloromethyl ketone (TPCK; Sigma), sodium dodecyl sulfate (SDS; Serva), $\mathrm{CaCl}_{2}$ (Serva), $\mathrm{CdCl}_{2}$ (Merck), $\mathrm{CuCl}_{2}$ (Merck), $\mathrm{HgCl}_{2}$ (Merck), and $\mathrm{ZnCl}_{2}$ (Merck) on the protease activity were examined. The concentration of each reagent was indicated in Table 2. After incubation at $37^{\circ} \mathrm{C}$ for $60 \mathrm{~min}$, the changes of protease activity were determined by HPA assay as described above. 


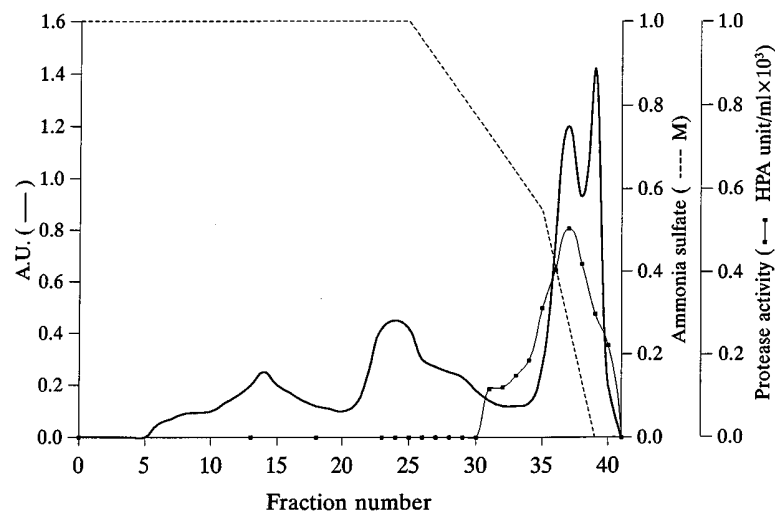

Fig. 1. Profile of FPLC-hydrophobic interaction chromatography (1st FPLC-HIC) of extracelluar products (ECP) of strain 820514. Sample was applied to Phenyl Sepharose High Performance column and eluted with stepped gradient of 1 to $0 \mathrm{M}$ ammonium sulfate in $50 \mathrm{~mm}$ phosphate buffer $\mathrm{pH} 7.0$ at a rate of $1 \mathrm{ml} / \mathrm{min}$.

\section{Results}

ECP of $V$. harveyi strain 820514. The ECP of strain 820514 were harvested after $24 \mathrm{~h}$ of incubation of the culture at $27^{\circ} \mathrm{C}$. The ECP showed caseinase, gelatinase, and lecithinase activities in tests on the agar plates. The protease (HPA digestibility) and hemolytic activities of the ECP were 551 units/mg protein and 24 hemolytic units/mg protein, respectively.

Purification of extracellular protease. ECP proteins of strain 820514 eluted as two major and two minor peaks in the first FPLC-HIC, with protease activity eluting between 0 and $0.6 \mathrm{M}$ ammonium sulfate (Fig. 1). Fractions (34-40) possessing protease activity were pooled, dialyzed, lyophilized, and eluted as two major and one minor peak in the second FPLC-HIC, with protease activity eluting between $0.10 \mathrm{M}$ and $0.55 \mathrm{~m}$ ammonium sulfate (data not shown). Fractions (18-25) possessing protease activity were pooled, dialyzed, lyophilized, and eluted as one major and two minor peaks in the FPLC-Q Sepharose High Performance, with protease activity eluting between $0.5 \mathrm{M}$ and $0.8 \mathrm{M} \mathrm{NaCl}$ (Fig. 2). Fractions (34-45) possessing protease activity were again pooled, dialyzed, lyophilized, and eluted as three major and two minor peaks in the FPLC-RESOURCE Q, with protease activity eluting between 0.5 and $0.9 \mathrm{M} \mathrm{NaCl}$ (data not shown). Fractions (46-59) possessing protease activity were again pooled, dialyzed, lyophilized, and eluted as one major and four minor peaks in the FPLC-Mono Q, with protease activity eluting between $0.3 \mathrm{M}$ and $0.5 \mathrm{M} \mathrm{NaCl}$ (Fig. 3). Fractions 10-14 collected from the major peak produced a single polypeptide band (Figs. 3,4) in SDS-PAGE. The purification of the protease is summarized in Table 1. A purification of approximately 12 -fold with a yield of $4.4 \%$ was achieved.

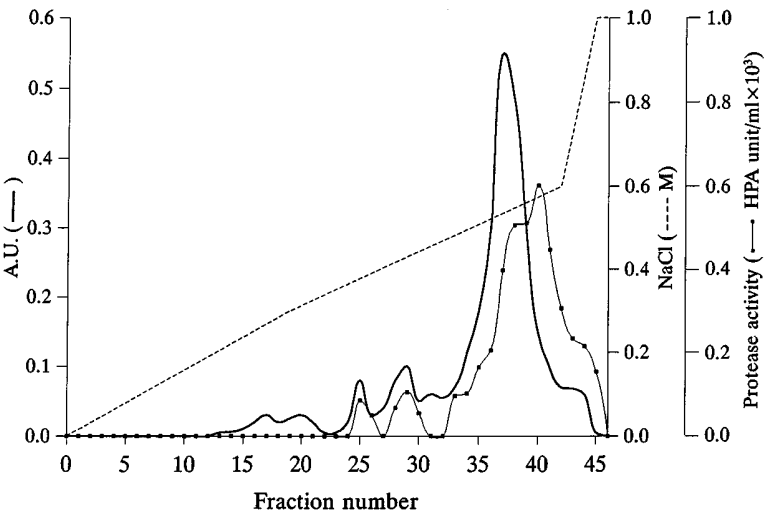

Fig. 2. Profile of FPLC-anion exchange chromatography of pools of fractions 18-25 from the 2nd FPLC-HIC. Sample was applied to Q Sepharose High Performance (QHP) column and eluted with stepped gradient of 0 to $1 \mathrm{M} \mathrm{NaCl}$ in $20 \mathrm{~mm}$ Tris buffer $\mathrm{pH} 8.0$ at a rate of 1 $\mathrm{ml} / \mathrm{min}$.

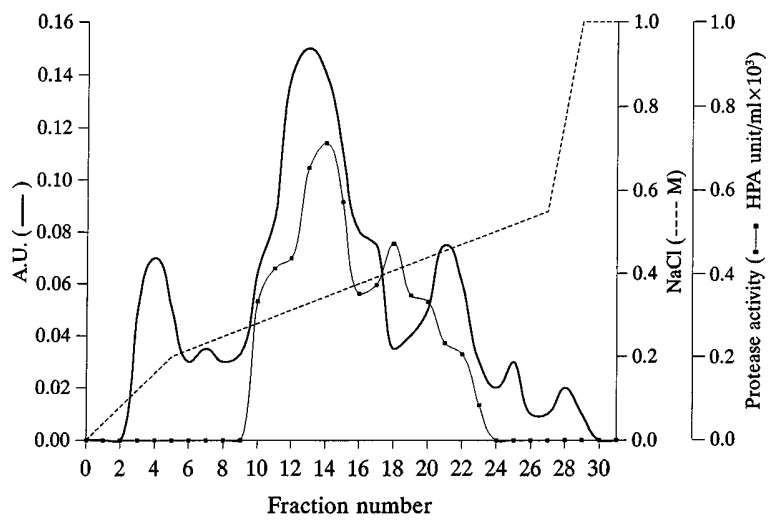

Fig. 3. Profile of FPLC-anion exchange chromatography of pools of fractions 46-59 from the RESOURCE Q column. Sample was applied to Mono Q column and separated as described in Fig. 2.

Molecular mass determination. The protein profiles of crude ECP and pools of proteolytic fractions in each purification step are shown in Fig. 4A. Pools of fractions 10-14 collected from FPLC-Mono Q produced only one single $38-\mathrm{kDa}$ polypeptide band in SDS-PAGE and, therefore, termed purified protease. Autodigestion of the purified protease apparently occurred during lyophilization, since nearly no band was stained in SDS-PAGE (Fig. 4A). The molecular mass of the purified protease was further confirmed by an estimation made by passage through an FPLC-Superose gel filtration, and also determined to be about $38 \mathrm{kDa}$ (Fig. 5).

Protease zymogram. Pools of fractions 10-14 collected from FPLC-Mono $Q$ also produced only one single polypeptide band in non-reduced SDS-PAGE, and this band exhibited caseinase activity in its protease zymogram (Fig. 4B). 

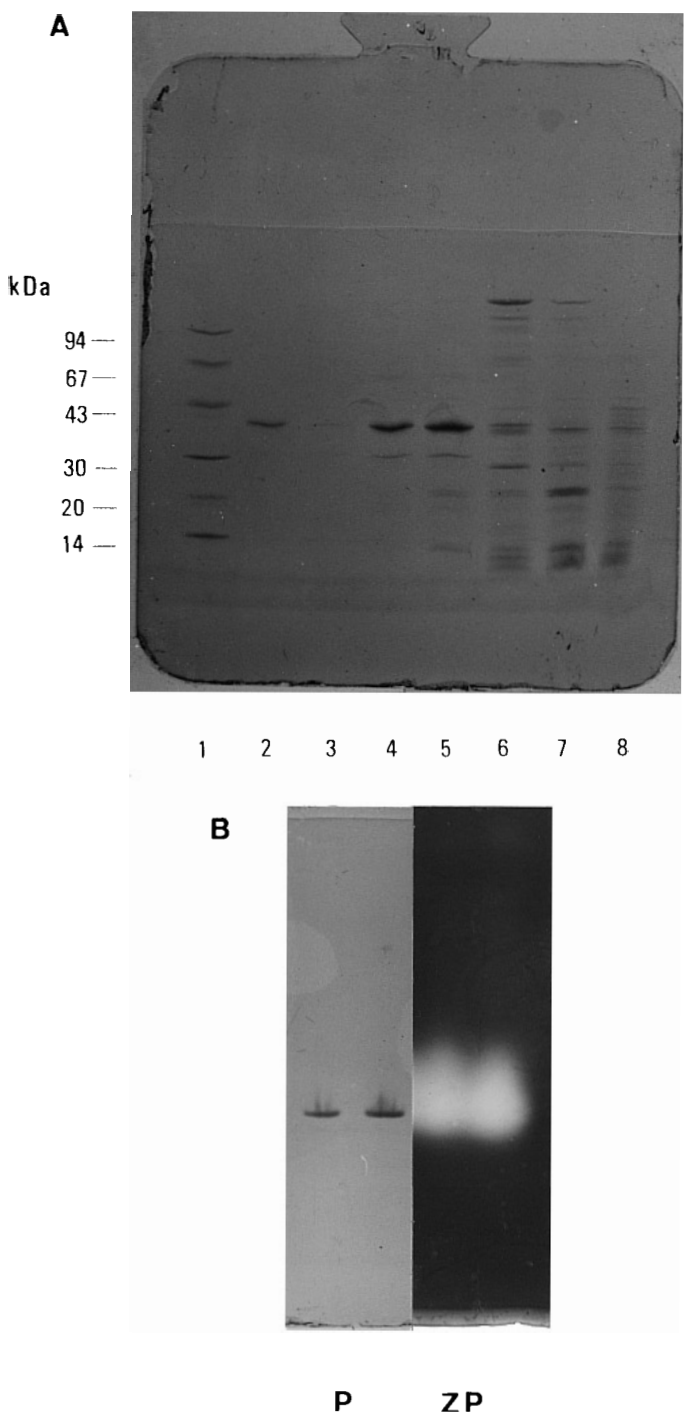

Fig. 4. (A) Protein profile of each purification step on SDS-PAGE (Phastgel, 8-25\% gradient). Lane 1, marker proteins (1.0 $\mu \mathrm{g})$; lane 2, purified protease from FPLC-Mono Q $(0.1 \mu \mathrm{g})$; Lane 3, purified protease after further lyophilization $(0.1 \mu \mathrm{g})$; lane 4 , pool of fractions 46-59 of FPLC-RESOURCE Q $(1 \mu \mathrm{g})$; lane 5, pool of fractions 34-45 of FPLC-Q Sepharose High Performance $(1 \mu \mathrm{g})$; lane 6, pool of fractions 18-25 of the 2nd FPLC-HIC (1 $\mu \mathrm{g})$; lane 7, pool of fractions $34-40$ of the 1st FPLC-HIC $(1 \mu \mathrm{g})$; lane 8 , ECP $(1 \mu \mathrm{g})$. The Phastgel was stained with Coomassie brilliant blue R 250. (B) SDS-PAGE (non-reduced, Phastgel gradient $8-25 \%$ ) and protease zymogram (casein agar overlaying gel) of the purified protease. Lane $P$, purified protease, stained with silver stain reagent; lane ZP, zymogram of purified protease, stained with Coomassie brilliant blue R 250 .

Optimum pH, optimum temperature, and thermostability. The purified protease showed maximal activities at $\mathrm{pH} 8.0$ and at $50^{\circ} \mathrm{C}$ (Fig. 6). For thermostability study, the relative protease activities of protease aliquots incubated at temperatures above $60^{\circ} \mathrm{C}$ were lower by more than $30 \%$ when compared with the activity when incubated at $4^{\circ} \mathrm{C}$ (Fig. 6), indicating that the purified protease was heat labile. In addition, the purified protease was autodigested after further lyophilization (Fig. 4A), suggesting that the enzyme was not stable even at low temperature.

Protease inhibition. As shown in Table 2, the purified protease was completely inhibited by iodoacetamide, iodoacetic acid, $N$-ethylmaleimide, PCMB, and PCMBs, indicating that the enzyme is a cysteine protease. In addition, the protease activity was also completely inhibited by $\mathrm{CuCl}_{2}$ and $\mathrm{HgCl}_{2}$, and only partially inhibited by $\mathrm{CdCl}_{2}, \mathrm{ZnCl}_{2}$, antipain, EGTA, E-64, pepstatin A, PMSF, and TLCK. However, activation of the enzyme activity was obtained with L-cysteine $(1.5 \mathrm{~mm})$, dithiothreitol, leupeptin, 2-mercaptoethanol (1.5 mM), higher concentrations (i.e., 5, $10 \mathrm{mM}$ ) of PCMB, TPCK, SDS, and $\mathrm{CaCl}_{2}$. A better inhibition of protease activity by $\mathrm{PCMB}$ was obtained only in low concentration (i.e., $1 \mathrm{mM}$ ), but in contrast the inhibition by L-cysteine or 2-mercaptoethanol was obtained in high concentration (10 mM). Furthermore, nearly half of the protease activity was inhibited by EDTA.

\section{Discussion}

Previous studies of the proteases from $V$. harveyi found that there are three types of metal-chelater-sensitive, alkaline proteases produced by the organism with a molecular mass of $84 \mathrm{kDa}$ (tetramer of $21 \mathrm{kDa}$ ) [10], 49 $\mathrm{kDa}$, and $46 \mathrm{kDa}$ (dimer of $23 \mathrm{kDa}$ ) [11]. However, the bacteria used in those studies were sea water isolates. In our present study, we were able to purify the $38-\mathrm{kDa}$ protease, determined on SDS-PAGE and FPLC-Superose 12 gel filtration (Fig. 4, 5), from extracellular products of pathogenic $V$. harveyi isolated from diseased tiger prawn (Penaeus monodon) by column chromatography on FPLCHIC and FPLC-anion exchange (Table 1). The purified protease revealed homogeneity on SDS-PAGE (Fig. 4A,B), and its enzymatic activity was shown in a matching zymogram gel with casein as substrate (Fig. 4B).

The purified protease exhibited optimum enzyme activities at $\mathrm{pH} 8.0$ and at $50^{\circ} \mathrm{C}$; these results are similar to the results reported by Fukasawa et al. [10, 11]. The enzyme showed a fairly wide range of optimum $\mathrm{pH}$ from 6 to 10 (Fig. 6), indicating that the production of this protease by the pathogenic $V$. harveyi might play a certain important role in marine environment and/or in tiger prawn. The purified protease was inactivated at temperatures above $60^{\circ} \mathrm{C}$ (Fig. 6) and was completely autodigested during further lyophilization (Fig. 4A), suggesting that the enzyme is heat labile.

In enzyme inhibition examination, the purified protease was completely inhibited by certain cysteine protease inhibitors: iodoacetamide, iodoacetic acid, N-ethylma- 
Table 1. Summary of purification of the protease from the extracellular products (ECP) of luminous Vibrio harveyi strain 820514

\begin{tabular}{|c|c|c|c|c|c|}
\hline Purification step & $\begin{array}{l}\text { Total protein } \\
\quad(\mathrm{mg})\end{array}$ & $\begin{array}{l}\text { Total activity }{ }^{a} \\
\quad \text { (units) }\end{array}$ & $\begin{array}{l}\text { Specific activity } \\
\quad \text { (units } / \mathrm{mg} \text { ) }\end{array}$ & $\begin{array}{l}\text { Purification factor } \\
\text { (fold) }\end{array}$ & $\begin{array}{c}\text { Yield } \\
(\%)\end{array}$ \\
\hline Crude ECP & 115.6 & 63,696 & 551 & 1.0 & 100.0 \\
\hline $90 \%$ ammonium sulfate fraction & 39.0 & 29,796 & 764 & 1.4 & 47.0 \\
\hline \multicolumn{6}{|c|}{$\begin{array}{l}\text { Hydrophobic interaction chromatography } \\
\text { (Phenyl Sepharose High Performance) }\end{array}$} \\
\hline First application & 9.4 & 13,470 & 1,433 & 2.6 & 21.0 \\
\hline Second application & 5.8 & 12,342 & 2,128 & 3.8 & 19.0 \\
\hline \multicolumn{6}{|l|}{ Anion exchange chromatography } \\
\hline Q Sepharose High Performance & 4.1 & 10,849 & 2,646 & 4.8 & 17.0 \\
\hline RESOURCE Q & 1.8 & 9,756 & 5,420 & 9.8 & 15.3 \\
\hline Mono Q & 0.4 & 2,821 & 6,716 & 12.2 & 4.4 \\
\hline
\end{tabular}

${ }^{a}$ Hide powder azure was used as the substrate for protease assay.

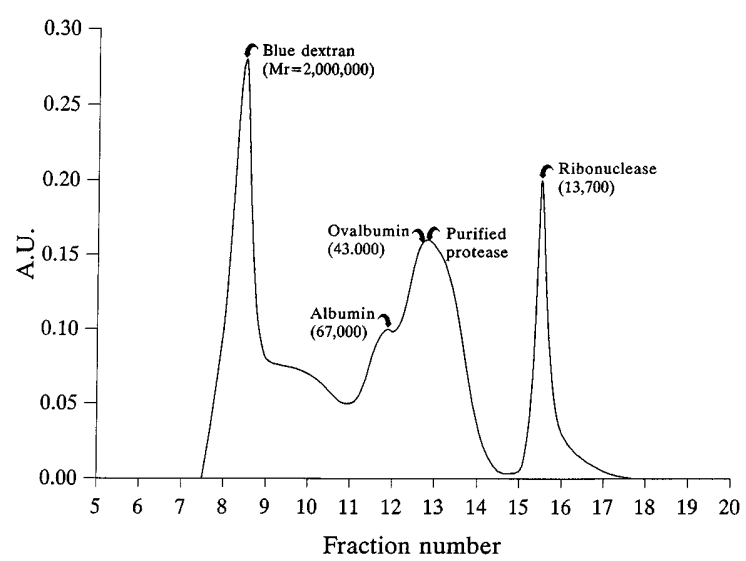

Fig. 5. Profile of purified protease eluted from FPLC-Superose 12 gel filtration column. Elution was with PBS, $\mathrm{pH} 7.2$, at a rate of $1 \mathrm{ml} / \mathrm{min}$. The column was calibrated with standard markers (Pharmacia), and points of peak elution are indicated. The molecular mass of blue dextran, bovine serum albumin, ovalbumin, and ribonuclease are 2000, 67,43 , and $13.7 \mathrm{kDa}$, respectively.

leimide, PCMB, and PCMBs; but was not or only partially inhibited by other protease inhibitors (i.e., acid protease: pepstatin A; metalloprotease: EDTA and EGTA; serine protease: PMSF) (Table 2). It was also completely inhibited by $\mathrm{CuCl}_{2}$ and $\mathrm{HgCl}_{2}$, while only partially inhibited by $\mathrm{CdCl}_{2}, \mathrm{ZnCl}_{2}$. Compared with the results reported by Fukasawa et al. [10, 11], our purified protease was similarly inhibited by $\mathrm{CuCl}_{2}$ and $\mathrm{HgCl}_{2}$, but was only partially inhibited by EDTA, $\mathrm{ZnCl}_{2}$, and $\mathrm{CdCl}_{2}$. Therefore, our present cysteine protease may not be the same protease $(s)$ reported by these authors $[10,11]$. Activation of the enzyme activity could be obtained with some reagents, i.e., L-cysteine $(1,5 \mathrm{~mm})$, dithiothreitol, leupeptin, 2-mercaptoethanol (1, $5 \mathrm{~mm})$, higher concentrations (5, $10 \mathrm{~mm}$ ) of PCMB, TPCK, SDS, and $\mathrm{CaCl}_{2}$ (Table 2); 2-mercaptoethanol (5 mM) (a cysteine protease enhancer) was the most effective reducing agent, while the other two cysteine protease enhancers, L-cysteine and dithio-

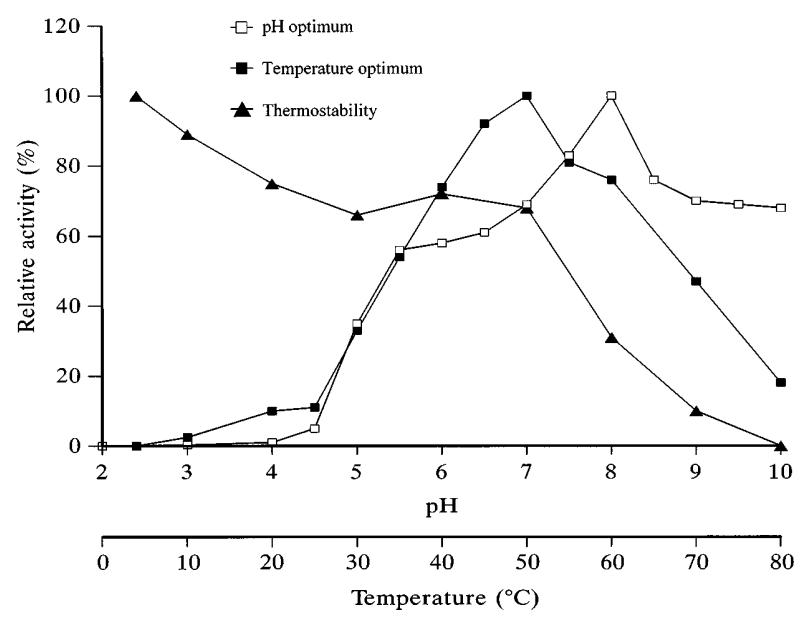

Fig. 6. Profiles of $\mathrm{pH}$ optimum, temperature optimum, and thermostability of the purified protease. For pH optimum (- $\square$-), the PBS buffer is in the $\mathrm{pH}$ range of 3-10 and hide powder azure (HPA) was used as substrate; for temperature optimum (- $\mathbf{-}$-), protease activities were assayed at $5,20,25,30,35,40,45,50,55,60,70$, and $80^{\circ} \mathrm{C}$, separately, and HPA was used as substrate; for thermostability (- $\mathbf{\Delta}$-), aliquots of the enzyme were incubated for $30 \mathrm{~min}$ at $4,10,20,30,40,50,60,70$, and $80^{\circ} \mathrm{C}$, separately, and then directly put into an ice/water bath prior to the HPA assay.

threitol, were not so effective compared with 2-mercaptoethanol (5 mM). Low levels (1, $5 \mathrm{~mm})$ of L-cysteine or 2-mercaptoethanol were able to activate the enzyme, while $10 \mathrm{~mm}$ might denature the enzyme as also demonstrated by Pike et al. [39] in a study on cysteine proteases from Porphyromonas gingivalis. However, the reason that $\mathrm{PCMB}$ can activate the protease activity at higher concentration of itself, in spite of its inhibitory effect at lower concentration, is still unknown.

The cysteine proteases (also termed thiol protease, sulfhydryl protease, or hydrolase) in mammals include several intracellular proteolytic enzymes (cathepsins B, $\mathrm{H}, \mathrm{L}$, and S) $[1,18,45,46]$, but the best-known members of this class are the plant proteases such as papain, 
Table 2. Effects of various concentration of reagents on the activity of Vibrio harveyi protease.

\begin{tabular}{|c|c|c|}
\hline Reagent & $\begin{array}{l}\text { Concentration } \\
(\mathrm{mM})\end{array}$ & $\begin{array}{c}\text { Relative activity } \\
\text { (\% of control) }\end{array}$ \\
\hline None & 0 & 100 \\
\hline \multicolumn{3}{|l|}{ Cysteine protease inhibitor: } \\
\hline \multirow[t]{2}{*}{ E-64 } & 1 & 100 \\
\hline & 5 & 69 \\
\hline Iodoacetamide & 10 & 25 \\
\hline Iodoacetic acid & 10 & 0 \\
\hline N-Ethylmaleimide & 10 & 0 \\
\hline \multirow[t]{3}{*}{$p$-Chloromercuribenzoate } & 1 & 28 \\
\hline & 5 & 105 \\
\hline & 10 & 120 \\
\hline p-Chloromercuribenzene- & 5 & 45 \\
\hline sulfonic acid & 10 & 0 \\
\hline \multicolumn{3}{|l|}{ Acid protease inhibitor: } \\
\hline Pepstatin A & 5 & 63 \\
\hline \multicolumn{3}{|l|}{ Metalloprotease inhibitor: } \\
\hline \multirow[t]{2}{*}{ EDTA } & 5 & 50 \\
\hline & 10 & 60 \\
\hline EGTA & 5 & 90 \\
\hline \multicolumn{3}{|l|}{ Serine protease inhibitor: } \\
\hline Phenylmethanesulfonyl fluoride & 5 & 66 \\
\hline \multicolumn{3}{|l|}{ Broad-spectrum protease inhibitor: } \\
\hline \multirow[t]{2}{*}{ Antipain } & 1 & 100 \\
\hline & 5 & 82 \\
\hline Leupeptin & 5 & 123 \\
\hline TLCK & 5 & 77 \\
\hline TPCK & 5 & 103 \\
\hline \multicolumn{3}{|l|}{ Other reagent: } \\
\hline \multirow[t]{3}{*}{ L-Cysteine } & 1 & 115 \\
\hline & 5 & 153 \\
\hline & 10 & 30 \\
\hline \multirow[t]{2}{*}{ Dithiothreitol } & 1 & 116 \\
\hline & 2 & 103 \\
\hline \multirow[t]{3}{*}{ 2-Mercaptoethanol } & 1 & 203 \\
\hline & 5 & 300 \\
\hline & 10 & 74 \\
\hline Sodium dodecyl sulfate & 5 & 106 \\
\hline \multicolumn{3}{|l|}{ Divalent metal ion: } \\
\hline $\mathrm{CaCl}_{2}$ & 5 & 106 \\
\hline $\mathrm{CdCl}_{2}$ & 5 & 79 \\
\hline $\mathrm{CuCl}_{2}$ & 5 & 9 \\
\hline $\mathrm{HgCl}_{2}$ & 5 & 1 \\
\hline $\mathrm{ZnCl}_{2}$ & 5 & 85 \\
\hline
\end{tabular}

EDTA: ethylenediamine tetraacetic acid.

EGTA: ethylene glycol-bis( $\beta$-amino-ethyl ether) $\mathrm{N}, \mathrm{N}, \mathrm{N}^{\prime}, \mathrm{N}^{\prime}$-tetraacetic acid.

E-64: trans-epoxysuccinyl-L-leucylamido-(4-guanidino)butane.

TLCK: N- $\alpha$-p-tosyl-L-lysine-chloromethyl ketone.

TPCK: N-tosyl-L-phenyl-alanine chloromethyl ketone.

bromelain, ficin, and ginger proteases (from papaya, pineapple, fig, and ginger, respectively) $[1,37]$. Although compounds E-64, leupeptin, and antipain are well known to be effective inhibitors of the papain family, these three compounds failed to effectively inhibit the purified cysteine protease, indicating that the present enzyme is a protease different from the papain family cysteine proteases.

Apart from the cysteine proteases found in animals and plants, the enzymes have also been demonstrated to play important roles in the disease process of some infectious agents such as viruses (picornavirus family) [50, 55], bacteria (P. gingivalis and Streptococcus pyogens) [4, 13, 39], parasites (Entamoeba histolytica, Myxosporidian parasite, Plasmodium falciparcum, and Trichomonas vaginalis) [19-21, 41, 47, 49, 52], in Alzheimer's disease [28], and in apoptosis (programmed cell death, mammalian interleukin-1 $\beta$-converting enzyme (ICE)-like proteases) [16, 23, 24, 32]. However, no such cysteine protease has ever been found to be produced by Vibrio species. As the majority of proteases previously studied in Vibrio species are metalloproteases $[9,14,26,31,33-35,53]$ and serine proteases [7, 12], and only a few non-vibrio (e.g., P. gingivalis, and Strep. pyogens) bacterial cysteine proteases $[4,13,39]$ have been studied so far, therefore, we conclude that our present study is the first isolation and characterization of a cysteine protease from Vibrio species known to date, and thus may contribute to the further understanding of bacterial cysteine proteases.

Since the present purified protease was found to be different from the cysteine proteases previously studied in many respects, it was extensively characterized in inhibitor studies. Inhibition and activation studies showed that it was a cysteine protease and that 2-mercaptoethanol was the most effective reducing agent in the activation of the enzyme. The enzyme was, therefore, suggested to be a new cysteine protease found in the ECP of V. harveyi.

\section{ACKNOWLEDGMENTS}

This work was supported by grants, COA-85-AST-1.13-FID-06(8)-2 and COA-85-1.4-FAD-01(9), from the Council of Agriculture, Republic of China. We thank F.-R. Chen and T.-I. Yang for technical assistance.

\section{Literature Cited}

1. Abeles RH, Frey PA, Jencks WP (1992) More hydroytic enzymes, blood clotting, and the antigen-antibody response. In: Abeles RH, Frey PA, Jencks WP (eds) Biochemistry. Boston: Jones and Bartlett Publishers, pp 154-159

2. Baticados MCL, Lavilla-Pitogo CR, Cruz-Lacierda ER, de la Pena LD, Sunaz NA (1991) Studies on the chemical control of luminous bacteria $V$. harveyi and $V$. splendidus isolated from diseased $P$. monodon larvae and rearing water. Dis Aquat Org 9:133-139

3. Baumann P, Baumann L, Mandel M (1971) Taxonomy of marine bacteria: the genus Beneckea. J Bacteriol 107:268-294

4. Berge A, Björck L. (1995) Streptococcal cysteine protease releases biologically active fragments of streptococcal surface proteins. J Biol Chem 270:9862-9867

5. Bradford MM (1976) A rapid and sensitive method for the quantitation of microgram quantities of protein utilizing the principle of protein-dye binding. Anal Biochem 72:248-254 
6. Chen SN, Huang SL, Kou GH (1992) Studies on the epizootiology and pathogenicity of bacterial infections in cultured giant tiger prawns, Penaeus monodon. In: Fulks W, Main KL (eds) Diseases of cultured penaeid shrimp in Asia and the United States. Hawaii: The Oceanic Institute, pp 195-205

7. Deane SM, Robb FT, Woods DR (1987) Production and activation of an SDS-resistant alkaline serine exoprotease of Vibrio alginolyticus. J Gen Microbiol 132:893-898

8. Egidius E (1987) Vibriosis: pathogenicity and pathology. A review. Aquaculture 67:15-28

9. Farrell DH, Crosa JH (1991) Purification and characterization of a secreted protease from the pathogenic marine bacterium Vibrio anguillarum. Biochemistry 30:3432-3436

10. Fukasawa S, Nakamura K, Kamii A, Ohyama Y, Osumi M (1988a) Purification and properties of a proteinase from a marine luminous bacterium, Vibrio harveyi strain FLA-11. Agric Biol Chem 52:435441

11. Fukasawa S, Nakamura K, Miyahira M, Kurata M (1988b) Some properties of two proteinases from a luminous bacterium, Vibrio harveyi strain FLN-108. Agric Biol Chem 52:3009-3014

12. Hare P, Scott-Burden T, Woods DR (1983) Characterization of extracellular alkaline proteases and collagenase induction in Vibrio alginolyticus. J Gen Microbiol 129:1141-1147

13. Imamura T, Potempa J, Pike RN, Travis J (1995) Dependence of vascular permeability enhancement on cysteine proteinases in vesicles of Porphyromonas gingivalis. Infect Immun 63:19992003

14. Inamura H, Nakai T, Muroga K (1985) An extracellular protease produced by Vibrio anguillarum. Bull Jpn Soc Sci Fish 51:19151920

15. Jiravanichpaisal P, Miyazaki T, Limsuwan C (1994) Histopathology, biochemistry, and pathogenicity of Vibrio harveyi infecting black tiger prawn Penaeus monodon. J Aquat Anim Health 6:27-35

16. Kamens J, Paskind M, Hugunin M, Talanian RV, Allen H, Banach D, Bump N, Hackett M, Johnston CG, Li P, Mankovich JA, Terranova M, Ghayur T (1995) Identification and characterization of ICH-2, a novel member of the interleukin-1 $\beta$ converting enzyme family of cysteine proteases. J Biol Chem 270:1525015256

17. Karunasagar I, Pai R, Malathi GR, Karunasagar I (1994) Mass mortality of Penaeus monodon larvae due to antibiotic-resistant Vibrio harveyi infection. Aquaculture 128:203-209

18. Kirschke H, Barrett AJ (1987) Chemistry of lysosomal proteases. In: Glaumann H, Ballard FJ (eds) Lysosomes: their role in protein breakdown. London: Academic Press, pp 193-238

19. Konagaya S (1980) Jellification and protease activity of yellowfin sole muscle in association with a Myxosporidian parasite. Bull Jpn Soc Fish Sci 46:1019-1026

20. Konagaya S (1982) Evaluation methods of the jellification grade of sporoa-infected yellowfin tuna meat, and the jellification rate. Bull Jpn Soc Fish Sci 48:543-548

21. Konagaya S (1983) Protease responsible for jellification of Myxosporidian infected swordfish meat. Bull Jpn Soc Fish Sci 49:919926

22. Kraxenberger-Beatty T, McGarey DJ, Grier HJ, Lim DV (1990) Vibrio harveyi, an opportunistic pathogen of the common snook, Centropomus unidecimalis (Bloch), held in captivity. J Fish Dis 13:557-560

23. Kuida K, Lippke JA, Ku G, Harding MW, Livingston DJ, Su MSS, Flavell RA (1995) Altered cytokine export and apoptosis in mice deficient in interleukin-1 $\beta$ converting enzyme. Science 267:20002003

24. Kumar S (1995) ICE-like proteases in apoptosis. Trends Biochem Sci 20:198-202

25. Lavilla-Pitogo CR, Baticados MCL, Cruz-Lacierda ER, de la Pena
LD (1990) Occurrence of luminous bacterial disease of Penaeus monodon larvae in the Philippines. Aquaculture 91:1-13

26. Lee KK (1995) Pathogenesis studies on Vibrio alginolyticus in the grouper, Epinephelus malabaricus, Bloch et Schneider. Microb Pathog 19:39-48

27. Lee KK, Ellis AE (1990) Glycerophospholipid: cholesterol acyltransferase complexed with lipopolysaccharide (LPS) is a major exotoxin and cytolysin of Aeromonas salmonicida: LPS stabilizes and enhances toxicity of the enzyme. J Bacteriol 172:5382-5393

28. Li QX, Evin G, Small DH, Multhaup G, Beyreuther K, Masters CL (1995) Proteolytic processing of Alzheimer's disease $\beta A 4$ amyloid precursor protein in human platelets. J Biol Chem 270:14140 14147

29. Liu PC, Lee KK, Chen SN (1996a) Pathogenicity of different isolates of Vibrio harveyi in tiger prawn, Penaeus monodon. Lett Appl Microbiol 22:413-416

30. Liu PC, Lee KK, Yii KC, Kou GH, Chen SN (1996b) Isolation of Vibrio harveyi from diseased kuruma prawns Penaeus japonicus. Curr Microbiol 33:129-132

31. Morita J, Suzuki S, Kusuda R (1994) Protease production profiles of the fish pathogen Listonella anguillara based on substrate specificities. Fish Sci 60:741-745

32. Munday NA, Vaillancour JP, Ali A, Casano FJ, Miller DK, Molineaux SM, Yamin TT, Yu VL, Nicholson DW (1995) Molecular cloning and pro-apoptotic activity of ICErel II and ICErel III, members of the ICE/CED-3 family of cysteine proteases. J Biol Chem 270:15870-15876

33. Norqvist A, Norrman B, Wolf-Watz H (1990) Identification and characterization of a zinc metalloprotease associated with invasion by the fish pathogen Vibrio anguillarum. Infect Immun 58:37313736

34. Nottage AS, Birkbeck TH (1987a) Purification of a proteinase produced by the bivalve pathogen Vibrio alginolyticus NCMB 1339. J Fish Dis 10:211-220

35. Nottage AS, Birkbeck TH (1987b) Production of proteinase during experimental infection of Ostrea edulis L. larvae with Vibrio alginolyticus NCMB 1339 and the antigenic relationship between proteinase produced by marine vibrios pathogenic for fish and shellfish. J Fish Dis 10:265-273

36. O'Brien CH, Sizemore RK (1979) Distribution of the luminous bacterium Beneckea harveyi in a semitropical estuarine environment. Appl Environ Microbiol 38:928-933

37. Ohtsuki K, Taguchi K, Sato K, Kawabata M (1995) Purification of ginger proteases by DEAE-Sepharose and isoelectric focusing. Biochim Biophys Acta 1243:181-184

38. Pass DA, Dybdahl R, Mannion MM (1987) Investigation into the causes of mortality of the pearl oyster, Pinctada maxima (Jamson), in Western Australia. Aquaculture 65:149-169

39. Pike R, McGraw W, Potempa J, Travis J (1994) Lysine- and arginine-specific proteinases from Porphyromonas gingivalis: isolation, characterization, and evidence of complexes with hemagglutins. J Biol Chem 269:406-411

40. Pizzutto M, Hirst RG (1995) Classification of isolates of Vibrio harveyi virulent to Penaeus monodon larvae by protein profile analysis and M13 DNA fingerprinting. Dis Aquat Org 21:61-68

41. Provenzano D, Alderete JF (1995) Analysis of human immunoglobulin-degrading cysteine proteinases of Trichomonas vaginalis. Infect Immun 63:3388-3395

42. Ramesh A, Venugopalan VK (1987) Luminous microflora associated with the fishes Mugil cephalus and Tachysurus arius. FEMS Microbiol Ecol 53:27-34

43. Ramesh A, Venugopalan VK (1989) Response of enteric luminous bacteria to environmental conditions in the gut of the fish. J Appl Bacteriol 66:529-533

44. Ramesh A, Nandakumar R, Venugopalan VK (1986) Enteric 
luminous microflora of the pond-cultured milk fish Chanos chanos (Forskal). Microb Ecol 12:231-235

45. Reddy VY, Zhang QY, Weiss S (1995) Pericellular mobilization of the tissue-destructive cysteine proteinases, cathepsins B, L, and S, by human monocyte-derived macrophages. Proc Natl Acad Sci USA 92:3849-3853

46. Roisen FJ, Kirschk H, Colella R, Wood L, St John AC, Fekete E, Li QS, Yorke G, Bird JWC (1983) An investigation of intracellular proteinases during differentiation of cultured muscle cells. In: Katunuma N, Umezawa H, Holzer H (eds) Proteinase inhibitors: medical and biological aspects. Tokyo: Jpn Sci Soc Press/Berlin: Springer-Verlag, pp 97-109

47. Rosenthal PJ, McKerrow JH, Aikawa M, Nagasawa H, Leech JH (1988) A malarial cysteine proteinase is necessary for hemoglobin degradation by Plasmodium falciparum. J Clin Invest 82:15601566

48. Ruby EG, Morin JG (1979) Luminous enteric bacteria of marine fish: a study of their distribution, densities and dispersion. Appl Environ Microbiol 38:406-411

49. Salas F, Fichmann J, Lee GK, Scott MD, Rosenthal PJ (1995) Functional expression of falcipain, a Plasmodium falciparum cysteine proteinase, supports its role as a malarial hemoglobinase. Infect Immun 63:2120-2125
50. Snijder EJ, Wassenaar ALM, Spaan WJM, Gorbalenya AE (1995) The arterivirus Nsp2 protease: an unusual cysteine protease with primary structure similarities to both papain-like and chymotrypsinlike proteases. J Biol Chem 270:16671-16676

51. Song YL, Lee SP (1993) Characterization of ecological implication of luminous Vibrio harveyi isolated from tiger shrimp (Penaeus monodon). Bull Inst Zool Acad Sin (Taipei) 32:217-220

52. Stanley SL Jr, Zhang T, Rubin D, Li E (1995) Role of the Entamoeba histolytica cysteine proteinase in amebic liver abscess formation in severe combined immunodeficient mice. Infect Immun 63:1587-1590

53. Stensvag K, Jorgensen TO, Hoffman J, Hjelmeland K, Bogwald J (1993) Partial purification and characterization of extracellular metalloproteases with caseinolytic, aminopeptidolytic and collagenolytic activities from Vibrio anguillarum. J Fish Dis 16:525539

54. Sunaryanto A, Mariam A (1986) Occurrence of a pathogenic bacteria causing luminescence in penaeid larvae in Indonesian hatcheries. Bull Brackishwater Aquacult Dev Cent 8:64-70

55. Walker PA, Leong LEC, Porter AG (1995) Sequence and structural determinants of the interaction between the 5 -noncoding region of picornavirus RNA and rhinovirus protease 3C. J Biol Chem 270:14510-14516 